\title{
Exploring copepod distribution patterns at three nested spatial scales in a spring system: habitat partitioning and potential for hydrological bioindication
}

\author{
Fabio STOCH, ${ }^{1}$ Barbara FIASCA, ${ }^{1}$ Tiziana DI LORENZO, ${ }^{2}$ Silvano PORFIRIO, ${ }^{1}$ Marco PETITTA, ${ }^{3}$ Diana M. P. GALASSI ${ }^{*}$ \\ ${ }^{1}$ Department of Life, Health and Environmental Sciences, University of L'Aquila, Via Vetoio, 67100 Coppito (AQ); ${ }^{2}$ Institute of \\ Ecosystem Study, National Research Council (CNR), Via Madonna del Piano 10, 50019 Sesto Fiorentino (FI); ${ }^{3}$ Department of Earth \\ Sciences, La Sapienza University, P.le A. Moro 5, 00185 Rome, Italy \\ *Corresponding author: dianamariapaola.galassi@univaq.it
}

\begin{abstract}
In groundwater-fed springs, habitat characteristics are primarily determined by a complex combination of geomorphic features and physico-chemical parameters, while species assemblages are even more intricate. Springs host species either inhabiting the spring mouth, or colonizing spring habitats from the surface or from the aquifers which feed the springs. Groundwater species living in springs have been claimed as good candidates for identifying dual aquifer flowpaths or changes in groundwater pathways before reaching the spring outlets. However, the reliability of spring species as hydrological biotracers has not been widely investigated so far. Our study was aimed at analysing a large karstic spring system at three nested spatial scales in order: i) to assess, at whole spring system scale, the presence of a groundwater divide separating two aquifers feeding two spring units within a single spring system, by combining isotope analyses, physico-chemistry, and copepod distribution patterns; ii) to test, at vertical spring system scale, the effectiveness of copepods in discriminating surface and subsurface habitat patches within the complex mosaic spring environment; iii) to explore, at local spring unit level, the relative role of hydrochemistry and sediment texture as describers of copepod distribution among microhabitats. The results obtained demonstrated the presence of a hierarchical spatial structure, interestingly reflected in significant differences in assemblage compositions. Copepod assemblages differed between the two contiguous spring units, which were clearly characterized by their hydrochemistry and by significant differences in the groundwater flowpaths and recharge areas, as derived by the isotope analyses. The biological results suggested that stygobiotic species seem to be related to the origin of groundwater, suggesting their potential role as hydrological biotracers. At vertical scale, assemblage composition in surface and subsurface habitats was significantly different, both between spring units and among microhabitats, supporting strong habitat preferences of copepod species. At the smaller local scale, the response to habitat patchiness of subsurface copepod assemblages resulted in distribution patterns primarily defined by sediment texture, while the sensitivity to differences in hydrochemistry was negligible.
\end{abstract}

Key words: Copepoda, groundwater, springs, aquifer, hydrochemistry, biological tracers.

Received: March 2015. Accepted: June 2015.

\section{INTRODUCTION}

Springs are one of the most widely distributed groundwater dependent ecosystems in the world (Eamus and Froend, 2006; Graillot et al., 2014) being included, with a few exceptions (e.g., springs fed by rainfall, snowmelt and glacier melt: Manga, 1996; Füreder et al., 2001; Brown et al., 2003), in the classification of Hatton and Evans (1998) as ecosystems entirely dependent on groundwater. In groundwater-fed springs, habitat features are primarily determined by a complex combination of geomorphic features and physico-chemical parameters (Serov et al., 2012), largely relying on groundwater temporal and spatial dynamics (Soulsby et al., 2007; Boy-Roura et al., 2013).

Biological assemblages are even more intricate, as springs are unique aquatic habitats, hosting species either preferentially or exclusively inhabiting spring mouths, or colonizing the spring from the surface (epigean species) or from the aquifer which feeds the spring (hypogean species) by a constant wash out (Rouch, 1968, 1982; Fiasca et al., 2014; Galassi et al., 2014). However, spring ecology has mainly focussed on the surface-water biota (Hahn, 2000; Bottazzi et al., 2011; Cantonati et al., 2011, 2012; Spitale et al., 2012), even if increasing attention is being paid to the fauna constantly living below the spring bed (Danks and Williams, 1991; Gerecke et al., 1998; Rossetti et al., 2005; Fiasca et al., 2014).

Habitat heterogeneity in spring environments (Gathmann and Williams, 2006; Barquín and Scarsbrook, 2008), and microhabitat partitioning of the manifold spring assemblages (Gerecke et al., 1998; Cantonati et al., 2011; 2012; Stoch et al., 2011; Fiasca et al., 2014) make it difficult to draw clear and unequivocal results on the ecological preferences of single species or entire assemblages (Spitale et al., 2012). Moreover, groundwater discharge variability is known to affect macroinvertebrate communities in springs (von Fumetti and Nagel, 2012). Groundwater discharge, together with spring habitat 
patchiness, has been analysed in detail in several rheocrenic springs (Hahn, 2000; Ilmonen et al., 2009; Bottazzi et al., 2011; Cantonati et al., 2011; 2012; Spitale et al., 2012), also at longitudinal spatial scale and over time (Spitale et al., 2012). Nevertheless, as far as we know, interactions between spring meiofauna assemblages and environmental parameters at nested spatial scales have never been fully explored.

Several organisms (invertebrates and bacteria) were considered good indicators of groundwater/surface water interactions in the hyporheic zone of streams and rivers (Lafont and Vivier, 2006; Stein et al., 2010; Bertrand et al., 2012; Di Lorenzo et al., 2013; Graillot et al., 2014). Similarly, beyond their uniqueness in terms of degree of endemism, rarity and relictuality (Galassi and De Laurentiis, 1997a, 1997b; Botosaneanu, 1998; Barquín and Scarsbrook, 2008; Galassi et al., 1999, 2011; Cantonati et al., 2011), some groundwater species have been claimed as good candidates for identifying dual aquifer flowpaths (Petitta et al., 2015; Mori et al., 2015) or changes in groundwater pathways feeding spring systems (Stoch et al., 2009; Galassi et al., 2014). However, the reliability of spring meiofauna assemblages as hydrological biotracers has not been investigated to any great extent.

The objectives of this study were to explore meiofauna distribution patterns in a karstic spring system of the Central Apennines in Italy. Considering that copepods (Crustacea: Copepoda) are by far the most abundant and species-rich group in groundwater habitats and springs (Galassi et al., 2014), they were selected as the target group (Galassi et al., 2009; Stoch and Galassi, 2010; Di Lorenzo and Galassi, 2013; Di Lorenzo et al., 2013; Caschetto et al., 2014). Copepod assemblages were studied at three nested spatial scales: i) at whole spring system scale, to test whether groundwater copepods can be reliable indicators of groundwater hydrological pathways, by combining isotope analyses, physicochemistry, and the composition of copepod assemblages; ii) at vertical spring system scale, to test the effectiveness of copepods in discriminating surface and subsurface habitat patches within the complex mosaic spring environment; iii) at local spring unit scale, to explore the relative role of hydrochemistry and sediment texture as describers of copepod distribution among microhabitats. The rheo-limnocrenic springs of the River Pescara (central Italy) constituted a paradigmatic case study because of their high discharge accompanied by high habitat heterogeneity (Galassi et al., 2011), and the co-existence of two spring units likely fed by two different karstic aquifers (Massoli Novelli et al., 1999).

\section{METHODS}

\section{Study area}

The springs of the River Pescara near Popoli (Abruzzi region, central Italy) are one of the main karstic spring systems of the central Apennines. Capo Pescara (WGS84 coordinates in decimal degrees: 42.163934, 13.821525) is a rheo-limnocrenic spring (mean discharge $6.2 \mathrm{~m}^{3} \mathrm{~s}^{-1}$ ), while Santa Liberata (coordinates: 42.168924, 13.820790) is a rheocrenic spring (mean discharge $1 \mathrm{~m}^{3} \mathrm{sec}^{-1}$ ) which flows into the main catchment, downstream of the Capo Pescara spring (Fig. 1).

In the central Apennines, the main karstic aquifers feed large springs with steady discharge regime. These springs are located at the contact between the carbonate rocks and the fluvio-lacustrine deposits (Petitta et al., 2011). The Gran Sasso aquifer (Fig. 1) has been studied in detail over the last 15 years (Galassi et al., 2014, and references therein; Tallini et al., 2014), revealing a unique regional, locally partitioned structure, characterized by gravity-driven groundwater flow (Tallini et al., 2013). Most of the Gran Sasso aquifer mean discharge $\left(23 \mathrm{~m}^{3} \mathrm{~s}^{-1}\right.$ : Amoruso et al., 2013) occurs at the south-eastern sector of the massif, where the springs of the River Pescara are located (Fig. 1). However, in previous studies, Massoli Novelli et al. (1999) inferred that the Gran Sasso aquifer discharge at the River Pescara spring system occurs predominantly at the Santa Liberata spring unit and less, or not at all, at the Capo Pescara spring. The Capo Pescara spring is supposed to be fed predominantly by the Sirente aquifer (Massoli Novelli et al., 1999), which is hydraulically in contact with the Gran Sasso ridge, where the spring system of the River Pescara is located (Fig. 1). The southernmost sector of the Sirente aquifer has hydrogeological features in terms of recharge similar to the Gran Sasso aquifer, and is overthrust towards NE on the Gran Sasso ridge, with a mean discharge of $8 \mathrm{~m}^{3} \mathrm{~s}^{-1}$.

\section{Sampling methods}

Taking into account the different location of the Santa Liberata spring unit respect to the main drainage of the Capo Pescara spring unit, a water isotope survey was carried out in order to assess differences in the recharge areas feeding both spring units (Fig. 1). Water samples (100 $\mathrm{mL})$ for isotope analyses $\left(\delta^{18} \mathrm{O}\right.$ and $\left.\delta \mathrm{D}\right)$ were collected five times during the hydrogeological year in 2012 from both spring units. Samples were analysed following the standard procedure (Longinelli and Selmo, 2003; Skrzypek, 2013) in the Isotope Lab at the University of Parma (analytical error $\pm 0.1 \%$ and $\pm 1 \%$, respectively for $\delta^{18} \mathrm{O}$ and $\left.\delta \mathrm{D}\right)$. The international standard adopted was Vienna Standard Mean Ocean Water (VSMOW) for both oxygen and hydrogen isotopes. The existing correlation between isotope values and elevation of the recharge area (CIRE, Computed Isotope Recharge Area, expressed as $\mathrm{m}$ asl) was assessed applying the formula used for the regional aquifer of the Gran Sasso massif: $\mathrm{CIRE}=\left(\delta^{18} \mathrm{O}\right.$ $+5.87) / 0.00256$ (Tallini et al., 2014).

A stratified random sampling was adopted in order to capture most of the environmental and biological hetero- 
geneity in the whole spring system. Abiotic and biological samples were taken at 12 sites (i.e., two epigean sites and four subsurface ones for each spring unit); samples were collected bimonthly from August 2011 to January 2013. Considering that in some hypogean sites sampling was not always possible due to constraints imposed by the hydrometric level, a total of 75 samples were collected. Surface benthic samples (mosses and surface sediments devoid of vegetation) were collected with a Hess sampler (mesh size: $60 \mu \mathrm{m}$; diameter: $40 \mathrm{~cm}$ ). Subsurface samples were collected from sediment patches and karstic fractures by a Bou-Rouch pump (Bou and Rouch, 1967), by extracting 10-L of water-sediments, using mobile pipes hammered at each sampling point-site at $50 \mathrm{~cm}$ depth, then filtered through a hand net (mesh size: $60 \mu \mathrm{m})$. Faunal samples were preserved in $80^{\circ}$ ethyl alcohol. In the laboratory, specimens were sorted under a stereomicroscope. Copepods were identified to species level and used as the target biological group. The collected copepod species were assigned to two ecological categories: epigean and non-obligate groundwater dwellers (i.e., non stygobiotic - nSB), and obligate groundwater dwellers (i.e., stygobiotic - SB), according to the definition of Galassi et al. (2009) and Di Lorenzo and Galassi (2013).

Sixteen physico-chemical parameters were measured in surface water and in all subsurface point-sites at each sampling date, simultaneously to the biological sampling. Temperature, $\mathrm{pH}$, specific conductivity at $25^{\circ} \mathrm{C}$, and dissolved oxygen (DO) concentration were measured in the field using a multiparametric probe (Yellow Springs Instruments, YSI 556 probe, Yellow Springs, OH, USA). Alkalinity and ionic content $\left(\mathrm{Cl}^{-}, \mathrm{F}^{-}, \mathrm{NH}_{4}^{+}, \mathrm{NO}_{3}^{-}, \mathrm{PO}_{4}{ }^{3-}\right.$, $\mathrm{SO}_{4}{ }^{2-}$, and $\mathrm{SiO}_{2}$ : standard methods APAT/IRSA CNR 29/2003; $\mathrm{Ca}^{2+}, \mathrm{Mg}^{2+}, \mathrm{Na}^{+}$, and $\mathrm{K}^{+}$: standard methods ISTISAN 07/31 ISS CBB 037/038, Ottaviani and Bonadonna, 2007) were measured by the Environment Protection Regional Agency of Abruzzo (ARTA). Additional samples were taken for measuring the grain-size composition of spring-bed sediments at each sampling site by using piezometers, with a screen with $8.0 \mathrm{~mm}$-diameter holes, and pumping $10 \mathrm{~L}$ of water/sediments at $50 \mathrm{~cm}$ depth at each point-site. The weight of eight granulometric classes was calculated per each site on the fractional dry-sieving of desiccated samples through a stack of

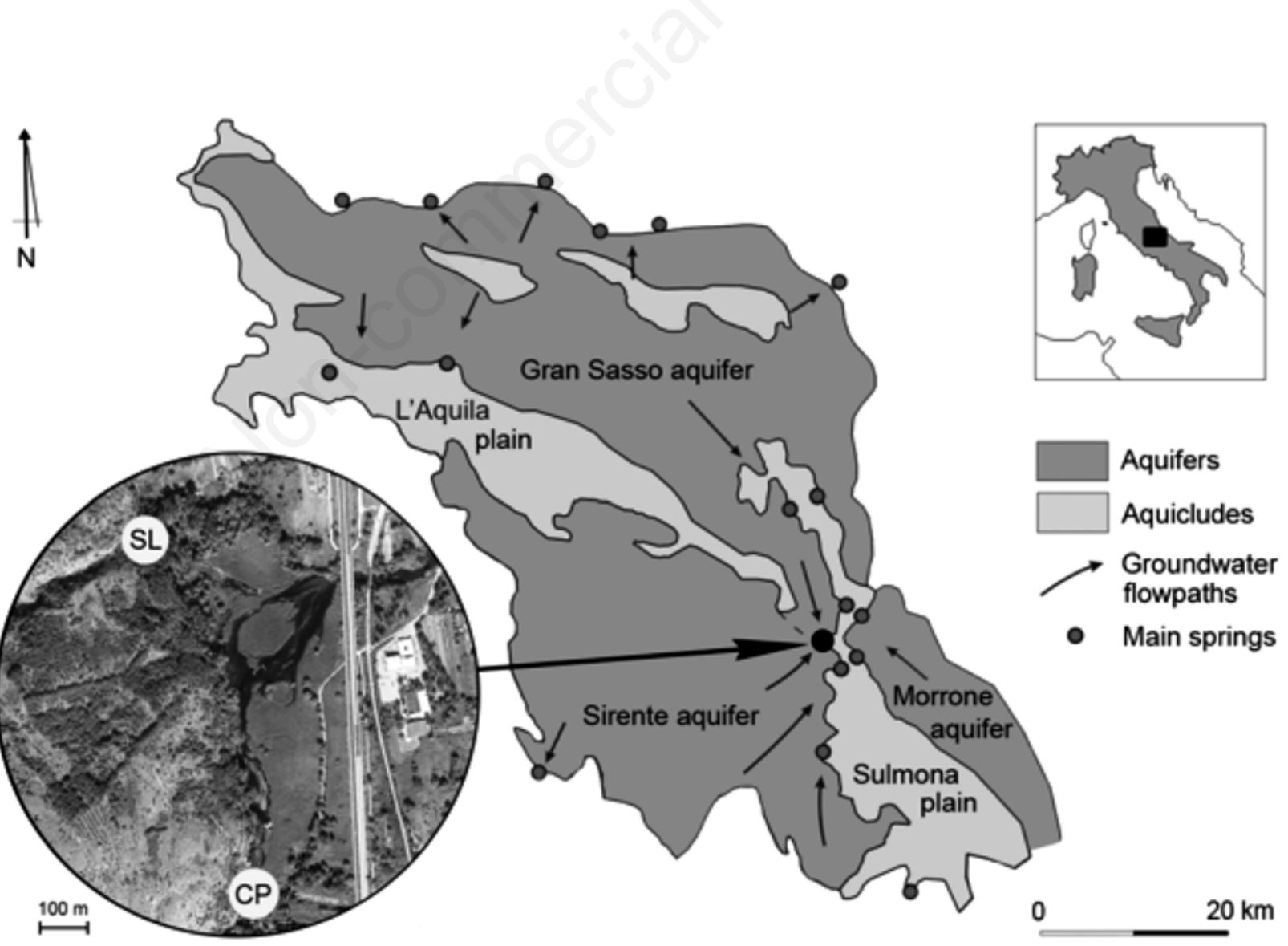

Fig. 1. Hydrogeological setting of the study area (the River Pescara spring system). Light grey areas, fluvial-lacustrine deposits (aquicludes); dark grey areas, karstic aquifers; left circle, orthophoto of the study area showing the locations of Capo Pescara (CP) and Santa Liberata (SL) spring units. 
sieves according to the Wentworth (1922) scale: pebbles (4-8 $\mathrm{mm}$ ), granules $(2-4 \mathrm{~mm})$; very coarse sand $(1-2 \mathrm{~mm})$, coarse sand $(0.5-1 \mathrm{~mm})$, medium sand $(0.25-0.5 \mathrm{~mm})$, fine sand $(0.125-0.25 \mathrm{~mm})$, very fine sand $(0.063-0.125 \mathrm{~mm})$, silt and clay $(<0.063 \mathrm{~mm})$.

\section{Data analysis}

Species richness estimations for the whole spring system and for the two spring units were performed using two non-parametric estimators based on the number of samples collected (i.e., Incidence Coverage-based Estimator - ICE - and Chao2 richness estimator). Estimators were calculated using the software EstimateS 9.1.0 (Colwell, 2013).

Nonmetric multidimensional scaling (nMDS) was performed in order to show the differences in species composition between assemblages; the Bray-Curtis index was selected to build the similarity matrix; a dummy variable was added to the data to deal with the large number of zero abundances in the samples. The importance of species in explaining nMDS two-axis plot was examined calculating the Spearman's correlation coefficient of each species with the first two axes. Assemblage differences at the larger spring system (Capo Pescara vs Santa Liberata spring units) and at the smaller microhabitat scale (e.g., mosses, surface sediments, subsurface fractures, and interstitial patches), considered as fixed factors, were explored in a nested hierarchy using the Permutational Multivariate Analysis of Variance (PERMANOVA, 9999 Monte Carlo permutations: Anderson, 2001). For all statistical analyses total counts of species were transformed using the Hellinger transformation to i) homogenize variation among species abundances; ii) allow comparison of counts of individuals collected from different microhabitats; and iii) make the dataset appropriate to be analysed using the multivariate methods explained below (Legendre and Legendre, 2012).

Environmental variables were standardized to zero mean and unit variance to account for their different scales of measurement. In order to describe the relationships between environmental variables and distribution patterns of copepods, multivariate analysis methods for paired sequences of ecological tables (i.e., environmental and species abundance data collected from different sites and at different times: Thioulouse, 2011) were used. BetweenGroup Co-Inertia Analysis (BGCOIA: Franquet et al., 1995) was selected as the most straightforward (Thioulouse, 2011), and giving outputs easy to interpret. The advantages of Co-Inertia analysis are well known (Dray et al., 2003); it has no the restrictions of other methods (e.g., Canonical Correspondence Analysis and Redundancy Analysis) that, involving a regression step, require linearly independent explanatory variables. Belonging to the descriptive approach, the BGCOIA may be used even with spatial and temporal replicates and is a robust alternative to other canonical analyses when the number of samples is low compared to the number of environmental variables (Dray et al., 2003). The multivariate analyses were performed on the whole dataset and separately for the subsurface samples, by including the granulometric variables in addition to the physico-chemical parameters.

Hellinger transformation and variable standardization were implemented using the function decostand in the vegan package (Oksanen et al., 2011) in R ver. 3.1.2 (R Development Core Team, 2013). nMDS and PERMANOVA were performed using the PRIMER computer package (Clarke and Gorley, 2006). Finally, BGCOIA was carried out using the ade4 package in R (Dray et al., 2007).

\section{RESULTS}

\section{Isotope analyses}

The isotope analyses revealed a steady isotope signal for both springs; the standard deviation of water isotope values $\left( \pm 0.7 \%\right.$ for $\delta \mathrm{D}$ and $\pm 0.05 \%$ for $\left.\delta^{18} \mathrm{O}\right)$ was lower than the analytical error for both springs. The very low seasonal and annual changes suggested a deep and relatively long flowpath from the recharge areas.

Nevertheless, both spring units showed a slight but clear difference in isotope values. In the Capo Pescara spring unit, mean values of $-68.8 \%$ in $\delta \mathrm{D}$ and $-10.1 \%$ in $\delta^{18} \mathrm{O}$ were recorded, while the Santa Liberata spring unit showed similar but slightly less depleted mean values of $-66.9 \%$ in $\delta \mathrm{D}$ and $-9.9 \%$ in $\delta^{18} \mathrm{O}$. All surveys indicated differences between the two sampled springs wider than the analytical uncertainty. The existing correlation between isotope values and elevation of the recharge area (CIRE) indicated a recharge area at an elevation of about $1580 \mathrm{~m}$ asl for the values of $\delta^{18} \mathrm{O}$ recorded at the Santa Liberata spring unit. The more depleted values recorded at the Capo Pescara spring unit corresponded to a mean recharge area at an elevation of about $1650 \mathrm{~m}$ asl.

\section{Structure of copepod assemblages}

A total of 28 copepod species (Tab. 1) were collected, total abundances per sample varying from 1 to 568 individuals; 6326 individuals were counted and classified to species level. The assemblages comprised 11 stygobiotic and 19 non-stygobiotic species (Tab. 1). The number of samples containing copepods was evenly distributed between the two spring units of Capo Pescara (31 samples, $60 \%$ of collected specimens) and Santa Liberata (29 samples, $40 \%$ of collected specimens). The remaining 15 samples were empty.

The exhaustiveness of the sampling effort was confirmed by non-parametric estimators and by the decline of the uniques (i.e., species present in a single sample) with increasing sampling effort (Fig. 2). Actual estimates 


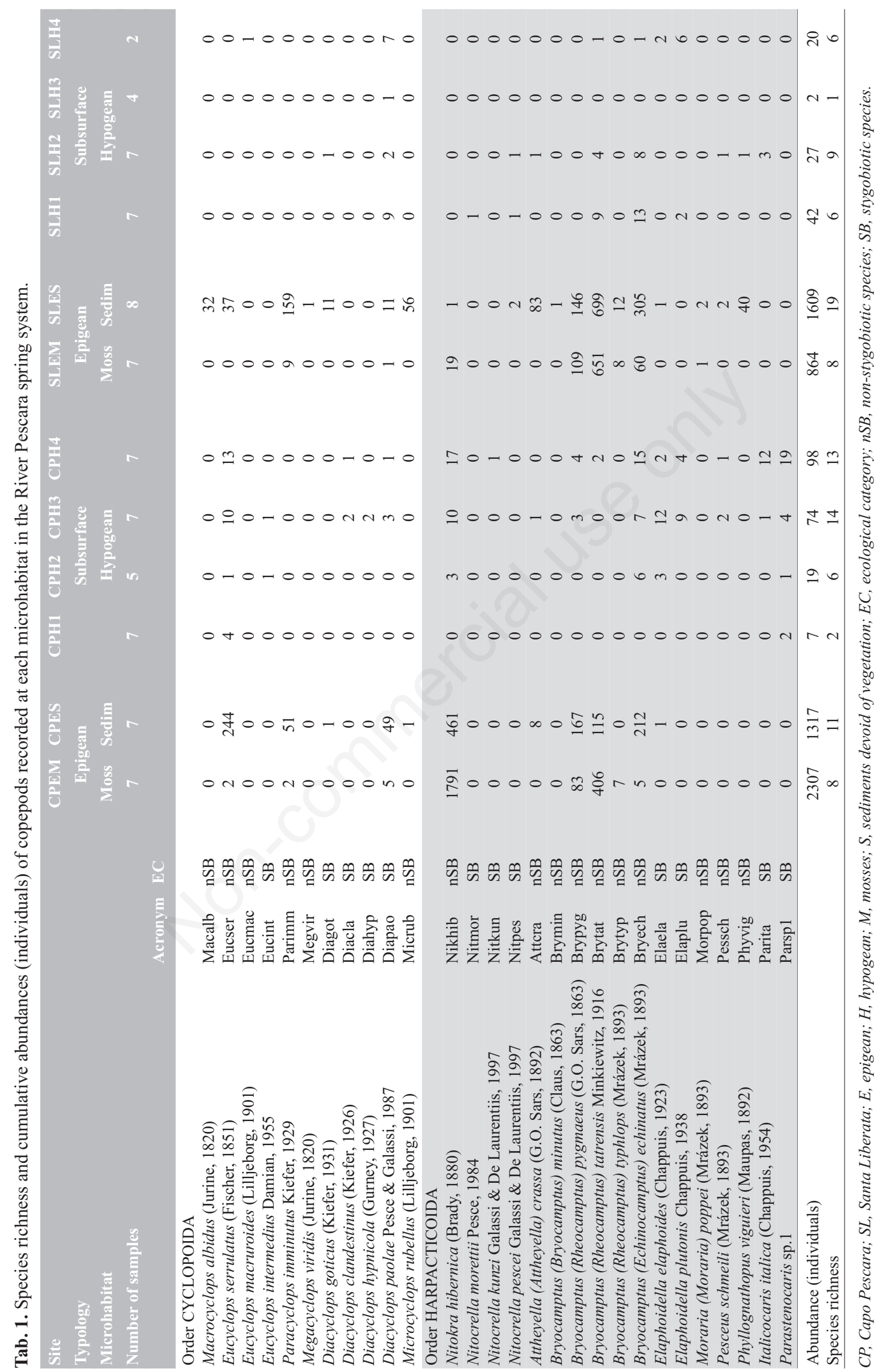


for copepod species richness in the spring system were around 30 species (i.e., over $93 \%$ of copepod species should have been collected during the sampling survey). The stygobiotic species Eucyclops intermedius, Diacyclops clandestinus, Diacyclops hypnicola, Parastenocaris sp. occurred only at the Capo Pescara spring unit; conversely, Nitocrella morettii and Nitocrella pescei occurred only at the Santa Liberata spring unit. The non-stygobiotic species Macrocyclops albidus, Eucyclops macruroides, Megacyclops viridis, Bryocamptus minutus, Moraria poppei and Phyllognatopus viguieri occurred only at the Santa Liberata spring. The other non-stygobiotic species co-occurred in both springs.

The two dimensional nMDS plot (Fig. 3) clearly distinguished hierarchical clusters of sites (stress: 0.2). The first axis in the plot separated subsurface and surface samples, while the second axis divided samples collected in the two spring units, namely Capo Pescara and Santa Liberata. Slight differences among surface microhabitats (e.g., mosses and sediment devoid of vegetation) are also shown in the graph (Fig. 3). Moreover, PERMANOVA returned significant differences $(\mathrm{P}<0.001)$ between assemblages inhabiting the two spring units at the largest scale, and among different microhabitats (mosses, surface sediments and subsurface sites) nested within spring units at the smallest scale.

\section{Environmental factors as describers of copepod assemblages}

The environmental parameters of different sites are summarized in Tab. 2. The results of the Between-Group Co-Inertia analysis performed on the whole dataset (species and physico-chemical parameters) explained $57.5 \%$ of the total variation (Fig. 4). The plot of sampling sites on the plane defined by the first two axes highlighted that water chemistry best described the part of total variation linked to the separation of the Capo Pescara and Santa Liberata spring units, clearly distinguishing the two clusters along the first axis (95.1\% of total explained inertia). Dissolved oxygen concentration was higher in the Santa Liberata spring than in the Capo Pescara spring. The second axis $(2.6 \%)$, dividing surface from subsurface samples, was described by higher $\mathrm{pH}$ (together with DO and temperature) in subterranean waters, and by higher phosphates and ammonium concentrations in surface waters. The species providing a significant contribution to the first two axes were: the non-stygobiotic Nitokra hibernica, which was present mainly in the epigean limnocrenic sites of the Capo Pescara spring; the stygobiotic Parastenocaris sp.1 and Eucyclops intermedius, which were exclusively linked to subsurface samples of the Capo Pescara spring; the non-stygobiotic Bryocamptus tatrensis and Paracyclops imminutus, which were highly represented in the surface benthic samples of the Santa Liberata spring; the stygobiotic Diacyclops paolae mainly associ- ated with the subsurface habitats of the Santa Liberata spring; the stygobiotic Diacyclops goticus, Nitocrella pescei and Nitocrella morettii exclusively found with low frequency of occurrence in the Santa Liberata groundwater. Finally, at whole spring system vertical scale, the stygobiotic Elaphoidella plutonis best described the subsurface sites, while its counterpart in surface-water habitats was the non-stygobiotic Bryocamptus pygmaeus.

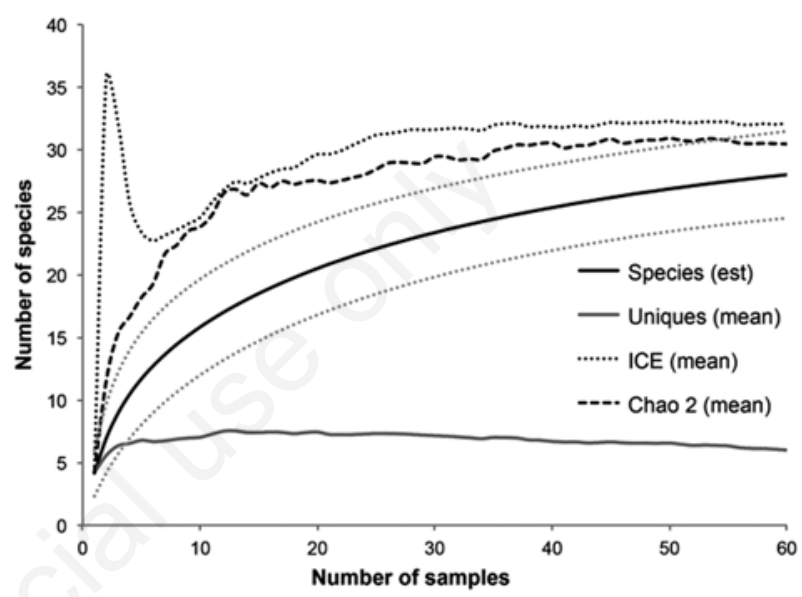

Fig. 2. Species rarefaction curves and estimators curves for copepods in the spring complex at increasing sample size. Species: species rarefaction curve of observed species richness (mean values estimated by mean of 999 randomizations without replacement); dotted grey lines represent $95 \%$ confidence limits. Uniques: curve of the mean number of species present in a single site. ICE, Chao 2: curves of the estimated species richness using mean values of the incidence-based estimator and Chao 2 formulas.

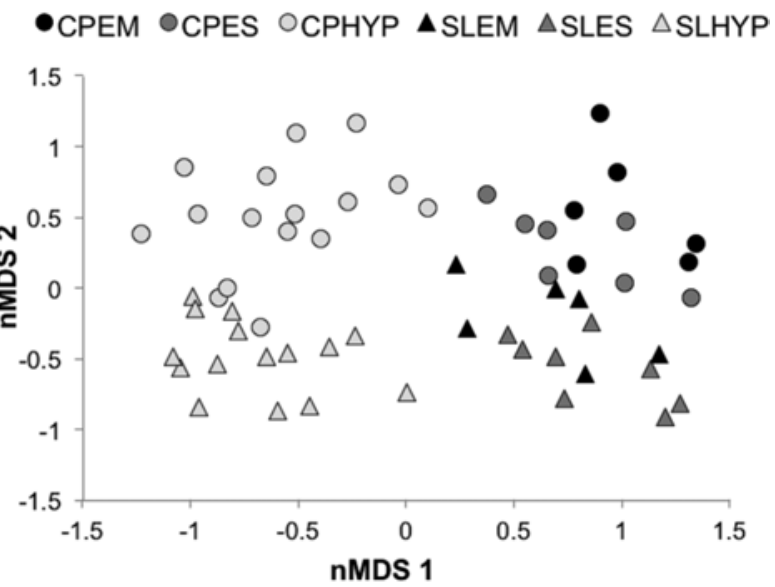

Fig. 3. Non-metric MDS plot (2D, stress: 0.20) of sampling sites. The legend reports spring codes (CP, SL) and microhabitat codes (EM, epigean, mosses; ES, epigean, sediments devoid of vegetation; HYP, hypogean habitats). 


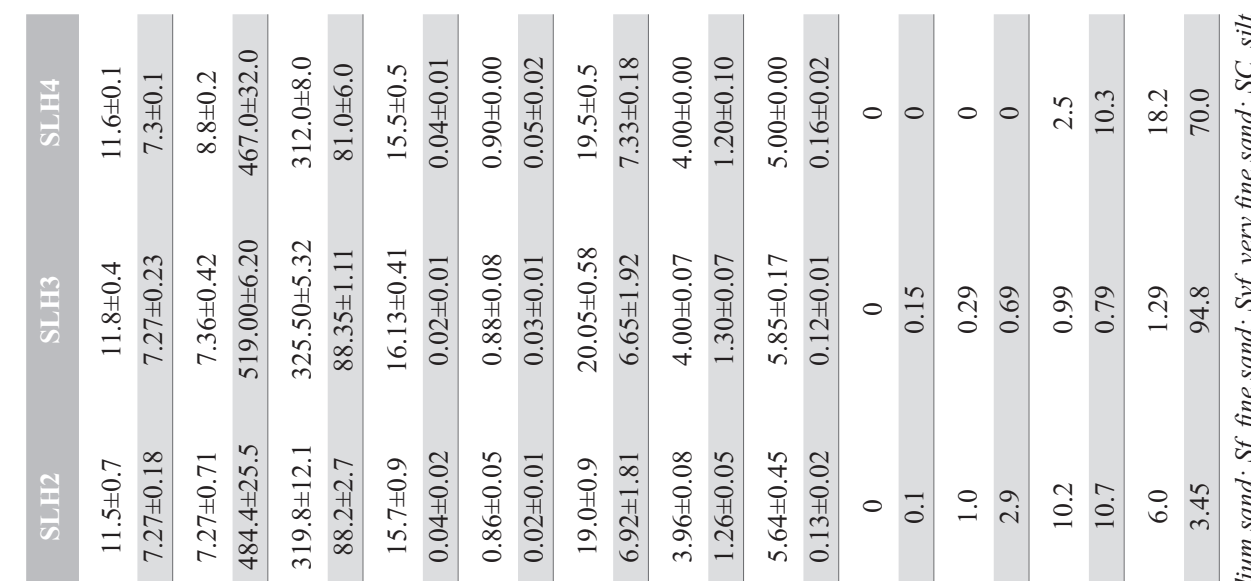

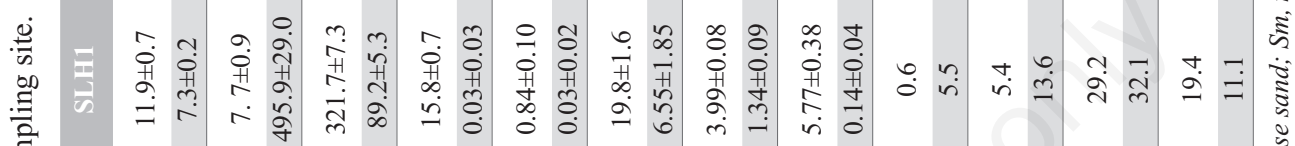

㫣

苂

훙

$\frac{0}{2}$

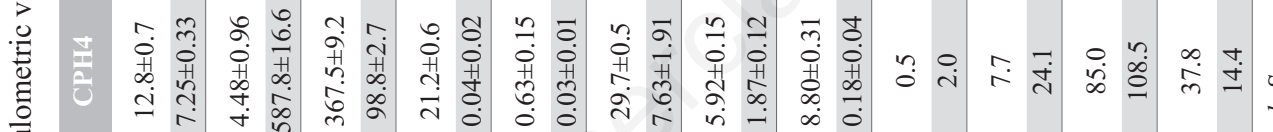

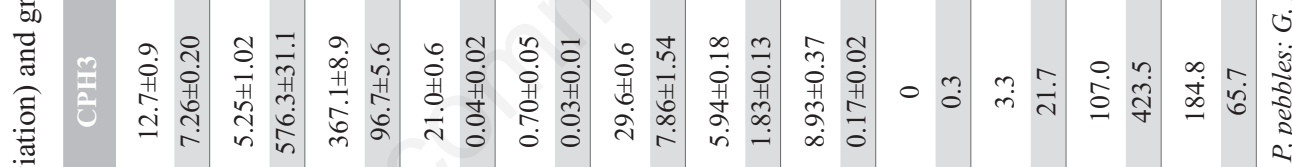

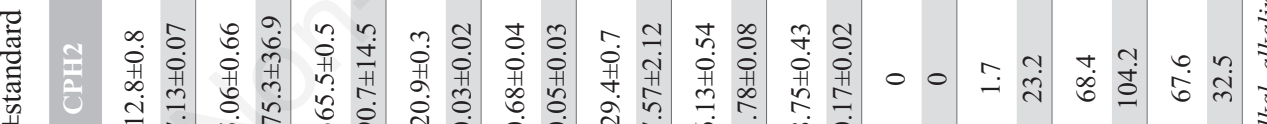

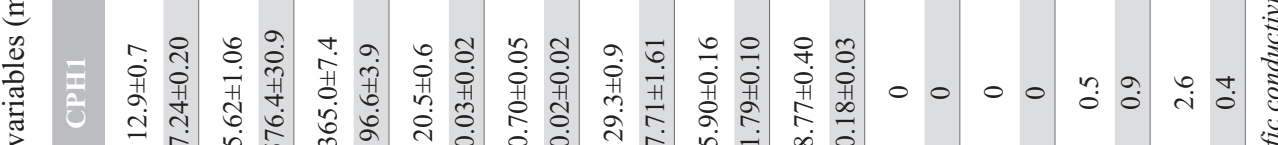

ब

등

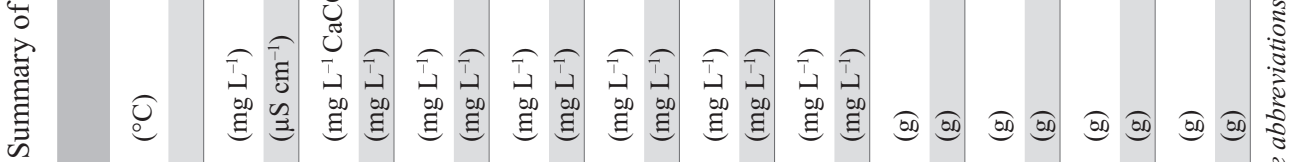

正 

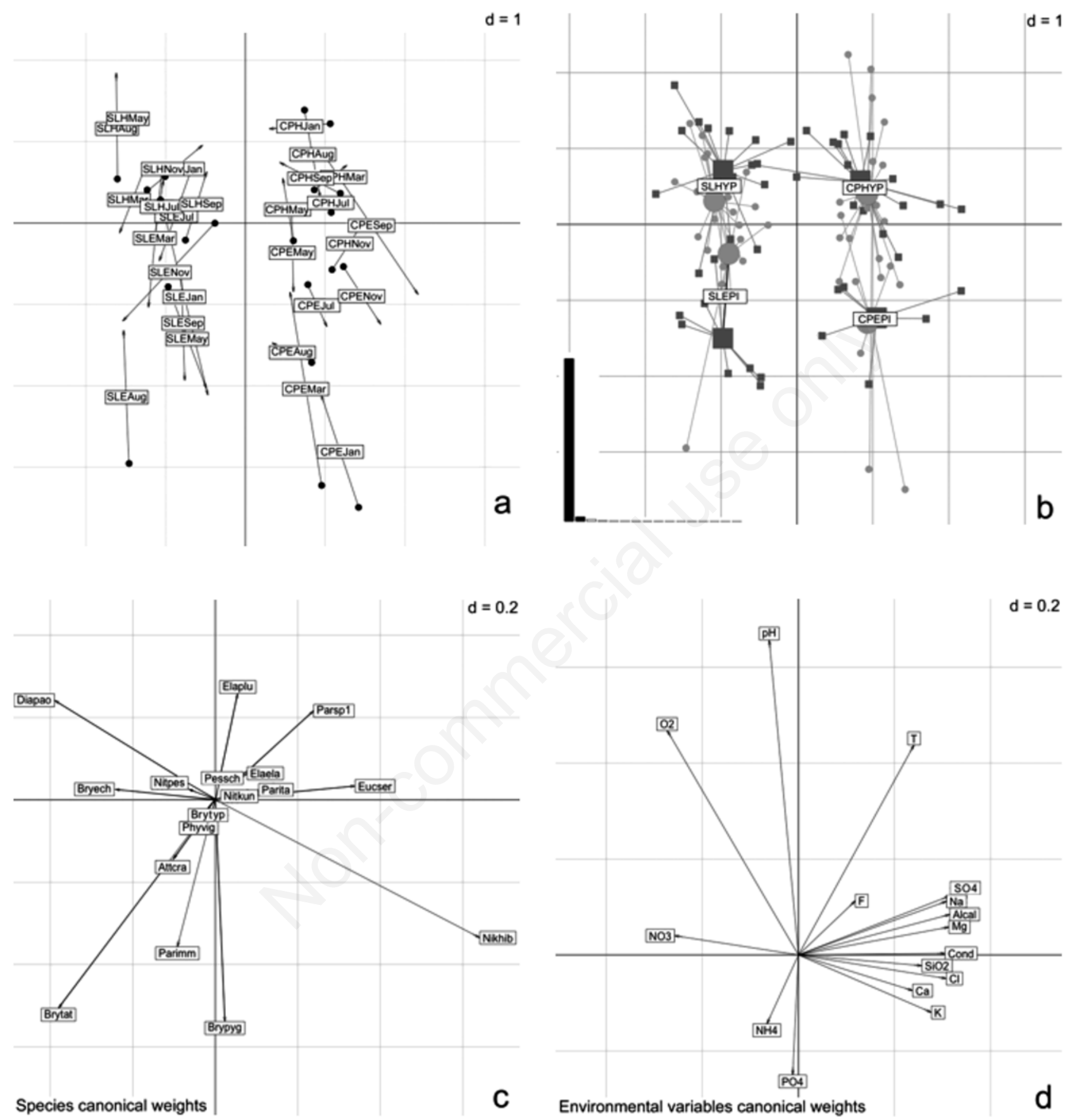

Fig. 4. First two principal axes maps of the between-group co-inertia analysis performed on the whole dataset table series. The scale (size of the background grid) is given by the value (d) in the upper right corner of each plot. a) Map of the samples (arrows starting at points derived by the physico-chemical variables table series and ending in points derived by the species table series) grouped by spring (SL, CP), horizon (E, epigean; H, hypogean), and month. b) Maps of samples grouped by spring and horizon (EPI, epigean; HYP, hypogean), with one set of points for the physico-chemical variables table sequence (grey circles, large circles representing barycentres) and one set of points for the species table sequence (grey squares, large squares representing barycentres); the bar plot in the lower left corner represents inertia explained by each axis (first axis: $95.2 \%$; second axis: $2.6 \%$ ). c) Map of the rows of the cross product table (canonical weights of species); species with very low canonical weights $(<0.05)$ were omitted for clarity; acronyms as in Tab. 1. d) Map of the columns of the cross product table (canonical weights of physico-chemical variables). 
In an attempt to detect further describers of species distribution in the subterranean habitats of the two springs, a Between-Group Co-Inertia analysis was repeated for the subsurface samples only. Granulometric variables were added to the physico-chemical variables to include sediment texture as an environmental describer of subsurface copepod assemblages. The analysis (Fig. 5) explained $81.7 \%$ of the total inertia, and different hypogean samples from the two spring units were again clearly separated along the first axis $(86.2 \%$ of explained inertia). The Capo Pescara spring unit was described by higher ionic content, mineralization, and the dominance of sand. Conversely, the Santa Liberata spring unit was characterized not only by a lower ionic content, but also by higher values of DO, nitrates, and $\mathrm{pH}$. Despite the high percentage of variation explained by the first axis, the fine-scale structure of the environmental mosaic within each spring unit was mainly defined by granulometry along the second axis (10.1\%), that represented a sharp gradient from pebbles, gravel, and coarse sand to silt. The contribution of the stygobiotic copepods (Fig. 5) to the axes was very strong for Diacyclops paolae, characterizing the fine sediments of the Santa Liberata spring, while coarse sediments in the same spring harboured the stygophylic Bryocamptus tatrensis and Bryocamptus echinatus. The stygobiotic species Diacyclops goticus was rare in the subsurface sites of the Santa Liberata spring unit, and, together with Nitocrella pescei and Nitocrella morettii, was never collected at the Capo Pescara spring unit. The stygobiotic Elaphoidella plutonis was mainly present in some sites of the Capo Pescara spring. The other hypogean sites of the Capo Pescara were characterized by the presence of three exclusive stygobiotic species, viz. Parastenocaris sp.1, Elaphoidella elaphoides and Eucyclops intermedius, never collected in the Santa Liberata spring unit, and two epigean species (Nitokra hibernica and Eucyclops serrulatus).

\section{DISCUSSION}

The hydrochemical differences observed in the two springs, mainly related to differences in DO concentration, $\mathrm{pH}$ values, electrical conductivity, alkalinity, and ionic content, may be related to differences in their recharge areas. The values of $\delta^{18} \mathrm{O}$ recorded at Santa Liberata indicated a lower elevation recharge area, corresponding to the main recharge area of the Gran Sasso aquifer (Petitta et al., 2015). Moreover, the elevation derived by the isotope signal is very similar to those recorded in springs located northwards (San Calisto and Tirino River Valley springs: Tallini et al., 2014), fed exclusively by the Gran Sasso aquifer. Values recorded at the Capo Pescara spring showed a mean recharge area of about $1650 \mathrm{~m}$ asl, indicating a slightly higher-altitude recharge area. Springs fed by the contiguous Sirente aquifer (Stiffe resurgence, Molina
Aterno and Acqua Solfa springs; Tallini et al., 2014) had a similar maximum CIRE of $1660 \mathrm{~m}$ asl. Consequently, as already hypothesized by Massoli Novelli et al. (1999), the Capo Pescara spring unit recharge may be attributed to groundwater originating predominantly from the Sirente aquifer, without excluding a possible minor contribution from the Gran Sasso aquifer.

At whole spring system scale, copepod assemblage composition at the two spring units primarily mirrored the significant differences observed in hydrochemistry and in the isotope signal, supporting the hypothesis that the Capo Pescara and Santa Liberata springs are fed by two different hydrogeological units. Six stygobiotic species have a potential role as tracers of groundwater flowpaths: Parastenocaris sp.1 and Eucyclops intermedius were exclusively linked to the Capo Pescara groundwater, while Nitocrella pescei, Nitocrella morettii and Diacyclops goticus were linked to the Santa Liberata groundwater. Nitocrella pescei was by far the most abundant species in fractured sectors of the spring-bed in the River Tirino springs (Galassi and De Laurentiis, 1997a; Fiasca et al., 2014; Galassi et al., 2014), the largest karstic springs exclusively fed by the Gran Sasso aquifer which feeds the Santa Liberata spring unit.

At vertical spring system scale, spring surface and subsurface habitats were clearly distinct and hosted significantly different copepod assemblages; this condition is expected in upwelling areas, where the number of surface species entering the subsurface is quite low, although not always negligible, as demonstrated by the high abundances of Nitokra hibernica and Eucyclops serrulatus in some subsurface sites of the Capo Pescara spring unit, especially in the limnocrenic sites, where low-current patches represent the preferred habitats for these species. The hydrochemistry poorly differentiated ground water from surface water, due to the strong groundwater upwelling in both springs. Most hydrochemical differences were related to a slightly higher amount of ammonium and phosphates in surface water, especially in the Santa Liberata spring, accompanied by a lower oxygen concentration, which may be due to runoff from surrounding agricultural areas. For this reason, species preferences and habitat structure may be invoked as the best explanatory factors at this hierarchical spatial level (vertical).

At the smaller scale, copepods were good describers of microhabitat structure both in surface and subsurface spring habitats. Although it is widely recognised that sediment texture influences local microhabitat structure and groundwater upwelling in streams (Swan and Palmer, 2000; Dole-Olivier, 2011) and springs (Fiasca et al., 2014), affecting the small-scale distribution of microcrustaceans, the role of hydrochemistry as a determinant of species distribution was established only on a broad spatial scale for spring meiofauna, including copepods 


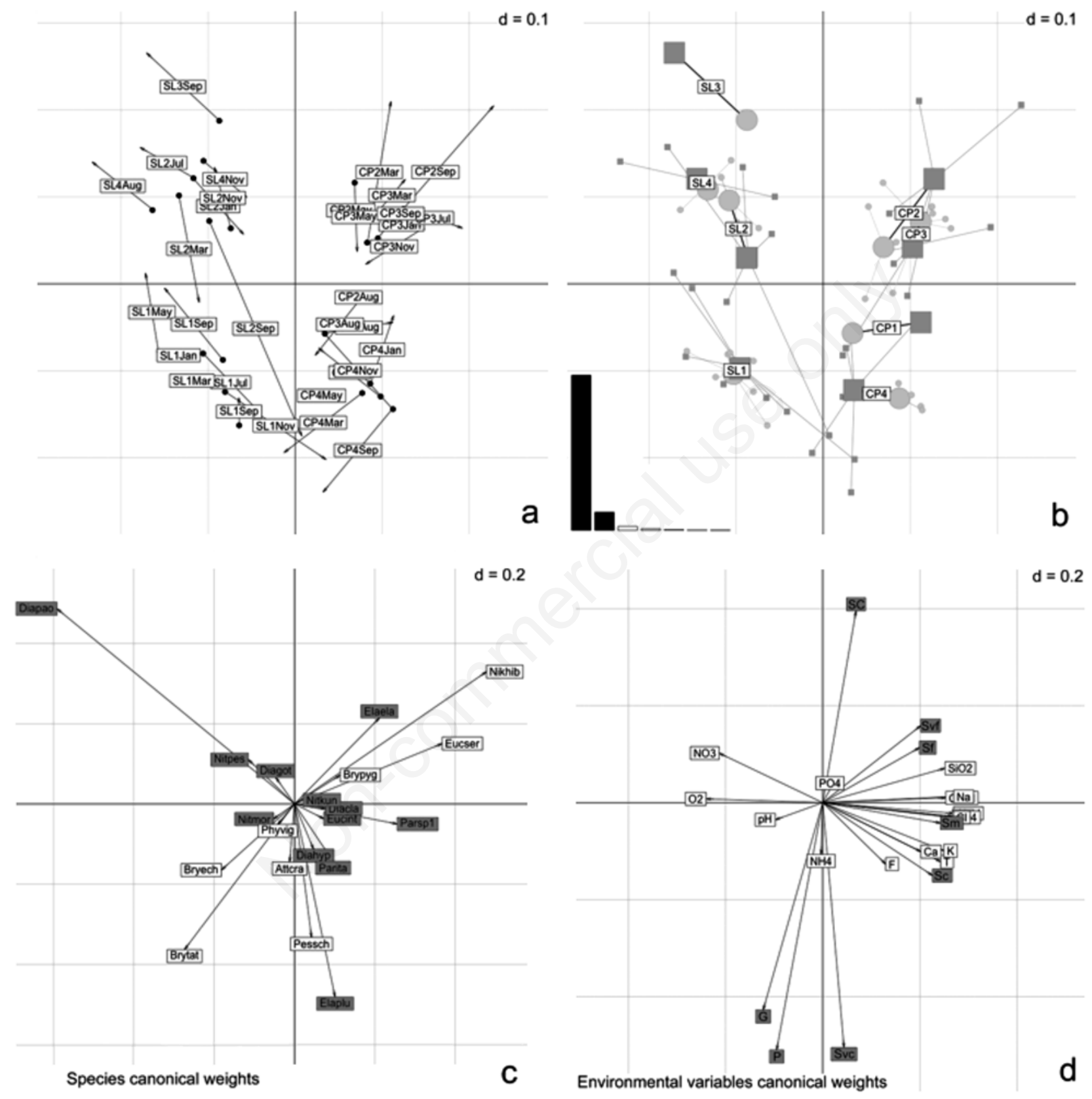

Fig. 5. First two principal axes maps of the between-group co-inertia analysis performed on the interstitial samples table series. The scale (size of the background grid) is given by the value (d) in the upper right corner of each plot. a) Map of the samples (arrows starting at points derived by environmental variables table series and ending in points derived by species table series) grouped by spring (SL, $\mathrm{CP}$ ), site (numeral), and month. b) Maps of samples grouped by spring and site, with one set of points for the environmental variables table sequence (grey circles, large circles representing barycentres) and one set of points for the species table sequence (grey squares, large squares representing barycentres); the bar plot in the lower left corner represents inertia explained by each axis (first axis: $86.2 \%$; second axis: $10.1 \%$ ). c) Map of the rows of the cross product table (canonical weights of species); acronyms as in Tab. 1; stygobiotic species label frames are greyed. d) Map of the columns of the cross product table (canonical weights of environmental variables); see Tab. 2 for codes; granulometric variables label frames are greyed. 
(Stoch et al., 2011). On a fine-scale, microhabitat structure at each spring unit was mirrored by copepod assemblage compositions both in surface and in subterranean environments. Surface microhabitats (mosses, sediments devoid of vegetation) hosted statistically different assemblages. The stygobiotic Diacyclops paolae preferred the true interstitial habitat of the spring-bed in the Presciano spring system (Fiasca et al., 2014), in agreement with the results of the present study, which confirmed the presence of D. paolae with high abundances in the fine sediments of the Santa Liberata spring unit. The subsurface environment structure was quite complex; the effect of sediment texture explained most of the variation of copepod assemblage structure among hypogean samples within each spring unit.

\section{CONCLUSIONS}

The analyses performed on the River Pescara spring system demonstrated the presence of a hierarchical spatial structure, interestingly reflected in copepod assemblage composition. Copepod assemblage composition differed between the two springs, which were clearly characterized by their hydrochemistry and by slight but significant differences in the groundwater flowpaths and recharge areas, as derived by the isotope analyses. The biological results suggest that the stygobiotic assemblages may be linked to the different hydrogeological units feeding the two springs, supporting their potential role as hydrological biotracers. However, the biological signal was not as strong as expected; this is likely due to the low abundance and frequency of occurrence of the obligate subterranean species, or to local ecological factors not detected during this study. Under the stygoscape perspective (Stanford and Gibert, 1994), we found that the biological signal reinforced the strong physico-chemical signal and the isotope signal.

At vertical scale, assemblage composition in surface and subsurface habitats was significantly different, both between springs and among microhabitats (mosses, surface sediments, and subsurface sites), suggesting strong habitat preferences of copepod species. At this scale, the explanatory power of the physico-chemical variables was rather low. At the smaller local scale, the response to habitat patchiness of subsurface copepod assemblages resulted in heterogeneous micro-distribution patterns primarily defined by sediment texture, while the sensitivity to differences in physico-chemistry was less marked at this scale. Indeed, hypogean species showed different distribution patterns mirroring habitat patchiness, in agreement with the results of the fine-scale analysis performed in another spring system in the Abruzzi region (the Presciano spring system: Fiasca et al., 2014).

Both studies clearly demonstrated that variation in hydrochemistry at the small scale had a minor effect in shaping patterns of subsurface copepod assemblages if compared to the strong explanatory role played by substratum texture.

\section{ACKNOWLEDGMENTS}

The project was funded by the European Community (LIFE12 BIO/IT/000231 AQUALIFE) and by Popoli Municipality (Pescara, central Italy).

\section{REFERENCES}

Amoruso A, Crescentini L, Petitta M, Tallini M, 2013. Parsimonious recharge/discharge modeling in carbonate fractured aquifers: the groundwater flow in the Gran Sasso aquifer (Central Italy). J. Hydrol. 476:136-146.

Anderson MJ, 2001. A new method for non-parametric multivariate analysis of variance. Aust. J. Ecol. 26:32-46.

APAT/IRSA CNR 29/2003. [Metodi analitici per le acque].[Report in Italian]. Available from: http://www.isprambiente. gov.it/it/pubblicazioni/manuali-e-linee-guida/metodi-analiticiper-le-acque

Barquín J, Scarsbrook M, 2008. Management and conservation strategies for coldwater springs. Aquat. Conserv. 18:580-591.

Bertrand G, Goldscheider N, Gobat J-M, Hunkeler D, 2012. From multi-scale conceptualization to a classification system for inland groundwater-dependent ecosystems. Hydrogeol. J. 20:5-25.

Botosaneanu L, 1998. Studies in Crenobiology: the biology of springs and springbrooks. Backhuys Publishers, Leiden: $261 \mathrm{pp}$.

Bottazzi E, Bruno MC, Pieri V, Di Sabatino A, Silveri L, Carolli M, Rossetti G, 2011. Spatial and seasonal distribution of invertebrates in Northern Apennine rheocrene springs. J. Limnol. 70:77-92.

Bou C, Rouch R, 1967. Un nouveau champ de recherches sur la faune aquatique souterraine. C. R. Acad. Sci. 265:369-370.

Boy-Roura M, Menció A, Mas-Pla J, 2013. Temporal analysis of spring water data to assess nitrate inputs to groundwater in an agricultural area (Osona, NE Spain). Sci. Total Environ. 452-453:433-445.

Brown LE, Hannah DM, Milner AM, 2003. Alpine stream habitat classification: an alternative approach incorporating the role of dynamic water source contributions. Arct. Antarct. Alp. Res. 35:313-322.

Cantonati M, Füreder L, Gerecke R, Jüttner I, Cox EJ, 2012. Crenic habitats, hotspots for freshwater biodiversity conservation: toward an understanding of their ecology. Freshwater Sci. 31:463-480.

Cantonati M, Gerecke R, Jüttner I, Cox EJ, 2011. Springs: neglected key habitats for biodiversity conservation. J. Limnol. 70:1-187.

Caschetto M, Barbieri M, Galassi DMP, Mastrorillo M, Rusi S, Stoch F, Di Cioccio A, Petitta M, 2014. Human alteration of groundwater-surface water interactions (Sagittario River, Central Italy): implication for flow regime, contaminant fate and invertebrate response. Environ. Earth Sci. 71:1791-1807.

Clarke KR, Gorley RN, 2006. PRIMER v6: User Manual/Tutorial. PRIMER-E, Plymouth.

Colwell RK, 2013. EstimateS, ver. 9.1: statistical estimation of species richness and shared species from samples (Software and User's Guide). 
Danks HV, Williams DD, 1991. Arthropods of springs, with particular reference to Canada. Mem. Entomol. Soc. Can. 155: 203-217.

Di Lorenzo T, Galassi DMP, 2013. Agricultural impact in Mediterranean alluvial aquifers: do groundwater communities respond? Fundam. Appl. Limnol. 182:271-282.

Di Lorenzo T, Stoch F, Galassi DMP, 2013. Incorporating the hyporheic zone within the river discontinuum: longitudinal patterns of subsurface copepod assemblages in an Alpine stream. Limnologica 43:288-296.

Dole-Olivier M-J, 2011. The hyporheic refuge hypothesis reconsidered: a review of hydrological aspects. Mar. Freshwater Res. 62:1281-1302.

Dray S, Chessel D, Thioulouse J, 2003. Co-inertia analysis and the linking of ecological data tables. Ecology 84:3078-3089.

Dray S, Dufour AB, Chessel D, 2007. The ade4 package-II: twotable and K-table methods. R News. 7:47-52.

Eamus D, Froend R, 2006. Groundwater-dependent ecosystems: the where, what and why of GDEs. Aust. J. Bot. 54:91-96.

Fiasca B, Stoch F, Olivier M-J, Maazouzi C, Petitta M, Di Cioccio A, Galassi DMP, 2014. The dark side of springs: what drives small-scale spatial patterns of subsurface meiofaunal assemblages? J. Limnol. 73:55-64.

Franquet E, Dolédec S, Chessel D, 1995. Using multivariate analysis for separating spatial and temporal effects within speciesenvironment relationships. Hydrobiologia 300-301:425-431.

Füreder L, Schütz C, Wallinger M, Burger R, 2001. Physicochemistry and aquatic insects of a glacier-fed and a springfed alpine stream. Freshwater Biol. 46:1673-1690.

Galassi DMP, De Laurentiis P, 1997a. Two new species of $\mathrm{Ni}$ tocrella from Italian groundwaters (Crustacea: Copepoda: Ameiridae). It. J. Zool. 64:367-376.

Galassi DMP, De Laurentiis P, 1997b. Pseudectinosoma reductum sp. n., a new ectinosomatid harpacticoid from spring waters in Italy (Crustacea: Copepoda). Hydrobiologia 356:81-86.

Galassi DMP, Dole-Olivier M-J, De Laurentiis P, 1999. Phylogeny and biogeography of the genus Pseudectinosoma, and description of $P$. janineae sp. n. (Crustacea: Copepoda, Ectinosomatidae). Zool. Scr. 28:289-303.

Galassi DMP, Fiasca B, Del Tosto D, 2011. Patterns of copepod diversity (Crustacea: Copepoda) in springs of Central Italy: implications for conservation issues s, p. 199-226. In: D. Defaye, E. Suárez-Morales and J.C. Vaupel Klein (eds.) Crustaceana monographs, studies on freshwater Copepoda: a volume in honour of Bernard Dussart. Brill NV, Leiden.

Galassi DMP, Huys R, Reid JW, 2009. Diversity, ecology and evolution of groundwater copepods. Freshwater Biol. 54: 691-708.

Galassi DMP, Lombardo P, Fiasca B, Di Cioccio A, Di Lorenzo T, Petitta M, Di Carlo P, 2014. Earthquakes trigger the loss of groundwater biodiversity. Sci. Rep. 4:6273.

Gathmann FO, Williams DD, 2006. Insect emergence in Canadian coldwater springs: spatial and temporal patterns, and species-environment relationships. Ann. Limnol.-Int. J. Lim. 42:143-156.

Gerecke R, Meisch C, Stoch F, Acri F, Franz H, 1998. Eucrenonhypocrenon ecotone and spring typology in the Alps of Berchtesgaden (Upper Bavaria, Germany). A study of microcrustacea (Crustacea: Copepoda, Ostracoda) and water mites (Acari: Halacaridae, Hydrachnellae), p. 167-182. In:
L. Botosaneanu (ed.), Studies in Crenobiology. The biology of springs and springbrooks. Backhuys Publisher, Leiden.

Graillot D, Paran F, Bornette G, Marmonier P, Piscart C, Cadilhac L, 2014. Coupling groundwater modeling and biological indicators for identifying river/aquifer exchanges. SpringerPlus 3:68

Hahn HJ, 2000. Studies on classifying of undisturbed springs in southwestern Germany by macrobenthic communities. Limnologica 30:247-259.

Hatton T, Evans R, 1998. Dependence of ecosystems on groundwater and its significance to Australia. Occasional Paper No. 12/98, Land and Water Resources Research and Development Corporation, CSIRO Australia: 77 pp.

Ilmonen J, Paasivirta L, Virtanen R, Muotka T, 2009. Regional and local drivers of macroinvertebrate assemblages in boreal springs. J. Biogeogr. 36:822-834.

Lafont M, Vivier A, 2006. Oligochaete assemblages in the hyporheic zone and coarse surface sediments: their importance for understanding of ecological functioning of watercourses. Hydrobiologia 564:171-181.

Legendre P, Legendre L, 2012. Numerical ecology. 3rd ed. Elsevier, Amsterdam.

Longinelli A, Selmo E, 2003. Isotopic composition of precipitation in Italy: a first overall map. J. Hydrol. 270:75-88.

Manga M, 1996. Hydrology of spring-dominated streams in the Oregon Cascades. Water Resour. Res. 32:2435-2439.

Massoli Novelli R, Petitta M, Salvati R, 1999. Monitoring and protection of groundwater resources: Capo Pescara karst spring (Central Italy), p. 449-454. In: Proceedings of the XXIX IAH Congress Hydrogeology and Land Use Management, Bratislava, Slovak Republik,

Mori N, Kanduč T, Opalički Slabe M, Brancelj A, 2015. Groundwater drift as a tracer for identifying sources of spring discharge. Groundwater 53(Suppl.1):123-132.

Oksanen J, Blanchet GF, Kindt R, Legendre P, O'Hara RB, Simpson GL, Solymos P, MHH Stevens, Wagner H, 2011. vegan: Community Ecology Package. R package ver. 1178. Available from: http://cran.r-project.org/web/packages/ vegan/index.html

Ottaviani M, Bonadonna L, 2007. [Metodi analitici di riferimento per le acque destinate al consumo umano ai sensi del DL.vo 31/2001. Metodi chimici].[Report in Italian]. Istituto Superiore di Sanità, Roma, Italy. Available from: http://www.salute. gov.it/imgs/C_17_pubblicazioni_2277_allegato.pdf

Petitta M, Caschetto M, Galassi DMP, Aravena R, 2015. Dualflow in karst aquifers toward a steady discharge spring (Presciano, central Italy): influences on a subsurface groundwater dependent ecosystem and on changes related to post-earthquake hydrodynamics. Environ. Earth Sci. 73:2609-2625.

Petitta M, Primavera P, Tuccimei P, Aravena R, 2011. Interaction between deep and shallow groundwater systems in areas affected by Quaternary tectonics (Central Italy): A geochemical and isotope approach. Environ. Earth Sci. 63:11-30.

R Development Core Team, 2013. R: A language and environment for statistical computing. R Foundation for Statistical Computing, Vienna, Austria.

Rossetti G, Pieri V, Martens K, 2005. Recent ostracods (Crustacea, Ostracoda) found in lowland springs of the provinces of Piacenza and Parma (Northern Italy). Hydrobiologia 542:287-296. 
Rouch R, 1968. Contribution à la connaissance des Harpacticides hypogés (Crustacés -Copépodes). Annls. Speleol. 23:5-167.

Rouch R, 1982. Le système karstique du Baget. XII. La communauté des harpacticides. Sur l'interdépendance des nomocénoses épigée et hypogée. Ann. Limnol.-Int. J. Lim. 18(1): 41-54.

Serov P, Kuginis L, Williams JP, 2012. Risk assessment guidelines for groundwater dependent ecosystems, 1 . The conceptual framework, NSW Department of Primary Industries, Office of Water, Sydney, Australia.

Skrzypek G, 2013. Normalization procedures and reference material selection in stable HCNOS isotope analyses - an overview. Anal. Bioanal. Chem. 405:2815-2823.

Soulsby C, Tetzlaff D, van den Bedem N, Malcolm IA, Bacon PJ, Youngson AF, 2007. Inferring groundwater influences on surface water in montane catchments from hydrochemical surveys of springs and streamwaters. J. Hydrol. 333:199-213.

Spitale D, Leira M, Angeli N, Cantonati M, 2012. Environmental classification of springs of the Italian Alps and its consistency across multiple taxonomic groups. Freshwater Sci. 31:563-574.

Stanford JA, Gibert G, 1994. Conclusion and perspectives, p. 543-547. In J. Gibert, D.L. Danielopol and J.A. Stanford (eds.), Groundwater eEcology. Academic Press, San Diego.

Stein H, Kellermann C, Schmidt SI, Brielmann H, Steube C, Berkhoff SE, Fuchs A, Hahn HJ, Thulin B, Griebler C, 2010. The potential use of fauna and bacteria as ecological indicators for the assessment of groundwater quality. J. Environ. Monit. 12:242-254.

Stoch F, Chiesi M, Tomasin G, Valenti D, 2009. [Il drift delle specie stigobie alle sorgenti di Poiano (Appennino Reggiano): relazioni con l'idrodinamica dell'acquifero].[Article in Italian]. Mem. Ist. Ital. Speleol. 2:129-144.

Stoch F, Galassi DMP, 2010. Stygobiotic crustacean species richness: a question of numbers, a matter of scale. Hydrobiologia 653:217-234.

Stoch F, Gerecke R, Pieri V, Rossetti G, Sambugar B, 2011. Exploring species distribution of spring meiofauna (Annelida, Acari, Crustacea) in the south-eastern Alps. J. Limnol. 70: 65-76.

Swan CM, Palmer MA, 2000. What drives small-scale patterns in lotic meiofauna communities? Freshwater Biol. 44:109-121.

Tallini M, Adinolfi Falcone R, Carucci V, Falgiani A, Parisse B, Petitta M, 2014. Isotope hydrology and geochemical modeling: new insights into the recharge processes and waterrock interactions of a fissured carbonate aquifer (Gran Sasso, central Italy). Environ. Earth Sci. 72:4957-4971.

Tallini M, Parisse B, Petitta M, Spizzico M, 2013. Long-term spatiotemporal hydrochemical and ${ }^{222} \mathrm{Rn}$ tracing to investigate groundwater flow and water-rock interaction in the Gran Sasso (central Italy) carbonate aquifer. Hydrogeol. J. 21:1447-1467.

Thioulouse J, 2011. Simultaneous analysis of a sequence of paired tables: a comparison of several methods. Ann. Appl. Stat. 5:2300-2325.

von Fumetti S, Nagel P, 2012. Discharge variability and its effect on faunistic assemblages in springs. Freshwater Sci. 31:647-656.

Wentworth CK, 1922. A scale of grade and class terms for clastic sediments. J. Geol. 30:377-392. 